\title{
New perspectives for surveying and improving Thai dried seafood qualities using antimicrobials produced by Bacillus velezensis BUU004 against foodborne pathogens
}

\author{
Namphueng Butkhot ${ }^{\mathrm{a}}$, Pornpimon Soodsawaeng ${ }^{\mathrm{b}}$, Sireeporn Samutsan ${ }^{\mathrm{a}}$, Kittikoon Chotmongcol $^{\mathrm{a}}$, \\ Verapong Vuthiphandchai ${ }^{\mathrm{c}}$, Subuntith Nimrat ${ }^{\mathrm{a}, \mathrm{d}, *}$ \\ ${ }^{a}$ Environmental Science Program, Faculty of Science, Burapha University, Chon Buri 20131 Thailand \\ b Biological Science Program, Faculty of Science, Burapha University, Chon Buri 20131 Thailand \\ c Department of Aquatic Science, Faculty of Science, Burapha University, Chon Buri 20131 Thailand \\ d Department of Microbiology, Faculty of Science, Burapha University, Chon Buri 20131 Thailand
}

*Corresponding author, e-mail: subunti@buu.ac.th

Received 25 Jan 2019

Accepted 30 Apr 2019

\begin{abstract}
Dried seafood products are one of the most popular seafood items in Thailand. This study was divided into two experiments. In first experiment, a survey in intrinsic and bacteriological characteristics of twenty dried seafood products distributed in Chon Buri province, Thailand was performed. Values of water activity, $\mathrm{pH}$ and $\mathrm{NaCl}$ content were $0.35 \pm 0.01-0.72 \pm 0.00,5.47 \pm 0.03-9.24 \pm 0.01$, and $0.66 \pm 0.06-2.26 \pm 0.03 \%$, respectively. Based on the Thai regulatory standard, half of dried seafood products contained total viable count over acceptable level. Predominant isolated bacteria in dried seafood products were Staphylococcus spp. (39.7\%), Bacillus spp. (30.1\%), and Pantoea sp. (19.2\%). Foodborne pathogens, i.e., B. cereus and Salmonella enterica serovar Weltevreden were found in dried seafood products. In second experiment, two forms of antimicrobials (concentrated (CBV) and partially purified (PBV) substances) prepared from B. velezensis BUU004 and two commercial preservatives (nisin and lactic acid) were introduced into crushed dried seasoned squids to investigate inhibitory activity against pathogens, $B$. cereus TISTR 687, S. aureus ATCC 25923, Salmonella Typhimurium TISTR 292, and Escherichia coli ATCC 25922. PBV had broader antagonistic activity than CBV, nisin and lactic acid against tested pathogens. Scanning electron microscopy analysis represented bacteriostatic action of PBV on tested pathogens through cell lysis evidenced by an irregular cell shape along with pore formation on cell membranes. Our study demonstrates that PBV has a preservative potential to control pathogen growth and improve biosafety of dried seafood products.
\end{abstract}

KEYWORDS: Bacillus velezensis, dried seafood products, antibacterial substances, biopreservative, foodborne pathogens

\section{INTRODUCTION}

Nowadays, dried seafood products represent a significantly economic importance to Thailand reaching a production of $51954 \mathrm{t}$ in 2017 estimated at $\$ 161$ million in revenues ${ }^{1}$. Eastern provinces of Thailand, Chon Buri, Rayong, Chanthaburi, and Trat, situated on an approximately $515 \mathrm{~km}$ coastline of the Gulf of Thailand, are major production areas of dried seafood products. In general, fishery products are extremely perishable, and their quality losses occur rapidly after caught. Traditional processes, e.g., sun-drying, salting, brining, marinating, smoking and fermenting, are applied in seafood stuffs for several days to delay spoilage and extend a shelf life due to decreased water activity, high salt content and changes in physical and biochemical characteristics $^{2,3}$. Even though dried seafood products can be stored for several months because of their stability at ambient temperature, they are also easily contaminated with foodborne pathogenic and spoilage bacteria. In Thailand, a variety recipe of dried seafood products is usually produced in small factories or household facilities with rudimentarily hygienic practices prior to being distributed to local markets and tourist attractions. In retail stores, the products are lapped from bulk containers into small plastic bags for sale and then tied with the rubber band, leading to potential hazard of foodborne ill- 
ness once pathogen contamination takes place in the products.

Dried seafood products are susceptible to a wide variety of potential pathogenic bacteria. Numbers of viable bacteria and pathogenic Bacillus cereus exceeded the allowable limit of Thai regulatory standard in dried seasoned squid products $(36.7 \%$ and $61.1 \%)^{4}$. Similarly, dried seafood products $(51.8 \%)$ collected from local markets in eastern provinces harboured viable bacteria numbers over the acceptable value ${ }^{5}$. This situation indicates that dried seafood products in eastern provinces of Thailand pose a serious risk for foodborne infection. As such, there is a dire need for managerial intervention to reduce a degree of bacterial contamination in dried seafood products and enhance seafood biosafety.

Natural antimicrobial substances from bacteria have become a topic of interest to control bacterial growth in food products ${ }^{6}$. It is an alternative procedure to chemical preservatives to ensure food safety and respond a growing consumer demand for processed products containing low levels or no chemical additives. Several antibacterial substances (ABS) produced by members of Bacillus genera represent a promising biopreservative in food systems such as antimicrobial peptides, lipopeptides and bacteriocins which display antibacterial activity against foodborne pathogens and spoilage bacteria $^{7}$. Unlike ABS produced by lactic acid bacteria (e.g., nisin) which have narrow antimicrobial spectrum and $\mathrm{pH}$ stability ${ }^{8}$, bioactive agents produced by Bacillus spp. have been receiving much interest in food industry owing to varied structural diversity, stability under wide range of environments and broad inhibitory spectrum ${ }^{7}$. Some Bacillus spp. have a long history of safe use in human food productions and animal feed supplements ${ }^{9}$. In recent years, ABS produced from Bacillus spp. have been reported to be a potential biopreservative in food systems ${ }^{10}$. There is currently scarce scientific information regarding role of $\mathrm{ABS}$ application in dried seafood products. Hence this study was designed to update situation of dried seafood biosafety in Chon Buri province, Thailand and investigate inhibitory efficiency of bacterial bioactive substances against foodborne pathogens in food model. First, we examined intrinsic and bacteriological characteristics of dried seafood products distributed in Chon Buri province. Second, we assessed inhibitory activity of ABS prepared from B. velezensis BUU004 against four pathogens, B. cereus TISTR 687, Staphylococcus aureus ATCC 25923, Salmonella Typhimurium TISTR 292, and Escherichia coli ATCC 25922 in crushed dried seasoned squids. Last, we studied action mode of ABS on cell morphology of the pathogens using scanning electron microscopy.

\section{MATERIALS AND METHODS}

\section{Sample collection of dried seafood products}

A total of 20 samples of dried seafood products were purchased from a retailer in local market in Chon Buri, Thailand. Collected dried seafood products were categorized into two types: (1) processed products that need minimum heating before consumption including dried fish and dried squids, and (2) cooked ready-to-eat products, i.e., crispy seasoned fish, crushed dried seasoned squids and sweet dried squid crisps. All samples were wrapped in sterile plastic bags, placed in an ice box and immediately transported to the laboratory within 30 min. Upon arrival at Environmental Microbiology Laboratory, Department of Microbiology, Faculty of Science, Burapha University, Thailand, all dried seafood samples were assessed for intrinsic and bacteriological qualities.

\section{Assessment of intrinsic properties of samples}

Analysis of intrinsic properties of dried seafood products was performed in terms of water activity $\left(a_{\mathrm{w}}\right), \mathrm{pH}$ value, and salt concentration. Water activity was determined using a LabSwift-aw water activity meter (Novasina AG, Switzerland) ${ }^{11}$. Value of $\mathrm{pH}$ was estimated by thoroughly homogenizing the sample $(10 \mathrm{~g})$ with sterile deionized water $(90 \mathrm{ml})$ for $5 \mathrm{~min}$ using a stomacher. Then, homogenate was measured directly using a calibrated digital $\mathrm{pH}$ meter (Metrohm 913, Metrohm Siam Ltd., Thailand). Salt content was determined using a back titration Volhard method and expressed as percentage of $\mathrm{NaCl}^{11}$. All measurements were accomplished in triplicate.

\section{Bacteriological analysis}

Dried seafood samples were evaluated for numbers of total viable count (TVC), S. aureus, E. coli and presence of Salmonella spp. Enumeration of TVC in this study was achieved using a spread plating technique in triplicate. Dried seafood samples (25 g) were excised aseptically, homogenized thoroughly with Butterfield's phosphate-buffered dilution water (BPW, $225 \mathrm{ml}$ ) in sterile plastic bag for 2 min using a stomacher. An aliquot $(0.1 \mathrm{ml})$ of each dilution was seeded onto Plate Count Agar (PCA; BD Difco, USA) ${ }^{12}$. All Petri dishes were incubated at $35^{\circ} \mathrm{C}$ for 24-48 h. Bacterial colonies grown on the medium 
were counted and expressed as colony forming units per gram $(\mathrm{CFU} / \mathrm{g})$. All isolates were purified and identified on the basis of morphological and biochemical characteristics ${ }^{13}$ and using API test kit (bioMerieux, France) following the manufacturer's instruction.

Enumeration of $S$. aureus and E. coli was performed according to US FDA's Bacteriological Analytical Manual (BAM) ${ }^{12}$ using a three-tube most probable number (MPN) method. A portion of sample $(25 \mathrm{~g})$ was homogenized in a stomacher bag containing BPW $(225 \mathrm{ml})$ and three decimal dilutions were made. Aliquots $(1 \mathrm{ml})$ of each dilution were inoculated into three tubes of Trypticase Soy Broth (TSB; BD Becto) containing $10 \% \mathrm{NaCl}$ and $1 \%$ sodium pyruvate. After incubation at $35^{\circ} \mathrm{C}$ for $48 \mathrm{~h}$, all turbid tubes were subcultured onto Baird-Parker agar (BD Difco) with egg yolk tellurite enrichment (HiMedia Laboratories, India) and incubated at $35^{\circ} \mathrm{C}$ for $48 \mathrm{~h}$. Suspicious colonies (black shiny convex colony with 2-3 $\mathrm{mm}$ in diameter surrounded by clear zone of approximately $2.5 \mathrm{~cm}$ ) were confirmed subsequently by coagulase test.

To count coliforms and $E$. coli, dried seafood samples (50 g) were thoroughly mixed with BPW $(450 \mathrm{ml})$ in stomacher bags. Then homogenates were 10-fold diluted and aspirated into a series of three-fermentation tube of Lauryl Tryptose broth (LST; BD Difco) and Brilliant Green Lactose Bile broth (BD Difco) for presumptive and confirmatory test of total coliform. After incubation at $35 \pm 0.5^{\circ} \mathrm{C}$ for $24 \pm 2 \mathrm{~h}$, a loopful of cultures in turbid tubes with gasses was inoculated into an EC broth (BD Difco) tube, then incubated at $44.5^{\circ} \mathrm{C}$ for $24 \pm 2 \mathrm{~h}$. Typical colonies were selected and confirmed by Eosin Methylene Blue agar (BD Difco) and subsequently tested by IMViC reactions. The MPN tables were used to calculate the approximate number of bacteria per gram ${ }^{12}$.

Presence of Salmonella spp. was detected in dried seafood product ${ }^{12}$. Dried seafood samples (25 g) were pre-enriched in 225-ml lactose broth and incubated at $35^{\circ} \mathrm{C}$ for $24 \pm 2 \mathrm{~h}$. Afterwards, an aliquot was inoculated in Tetrathionate (TT) broth (BD Difco) and Rappaport-Vassiliadis broth (BD Difco). All culture broths with turbidity were streaked onto Bismuth Sulphite Agar (BD Difco), Xylose Lysine Deoxycholate agar (BD Difco) and Hektoen Enteric Agar (BD Difco). After incubation at $35^{\circ} \mathrm{C}$ for $24 \pm 2 \mathrm{~h}$, Salmonella was confirmed by selected biochemical tests recommended by US FDA's BAM. Serotyping of Salmonella was characterized by sero-agglutination test (Bio-Rad, USA) following the Kauffmann-White scheme ${ }^{14}$.

\section{Procurement and culture of ABS producing bacteria}

B. velezensis BUU004 with the formerly taxonomic designation as $B$. licheniformis BUU004 was obtained from the Environmental Microbiology Laboratory, Department of Microbiology, Faculty of Science, Burapha University, Thailand. This bacterial strain was isolated from black tiger shrimp (Penaeus monodon) pond sediment ${ }^{15}$ and reported to be an aquaculture probiotic owing to improvement of feed efficiency, growth, survival and culture water quality of black tiger and whiteleg (Litopenaeus vannamei) shrimp and inhibition of shrimp pathogenic Vibrio ${ }^{15,16}$. Its genome sequence was studied and deposited in NCBI Bioproject under the accession number PRJNA508842. A single colony of this isolate was inoculated in a 250-ml flask containing 100-ml TSB and incubated in a shaking incubator at $200 \mathrm{rpm}, 30^{\circ} \mathrm{C}$ for $24 \mathrm{~h}^{15}$. Cell suspension was centrifuged at $8000 \mathrm{~g}$ for $10 \mathrm{~min}$ at $4^{\circ} \mathrm{C}$, then cellfree supernatant (CFS) was harvested for subsequent $\mathrm{ABS}$ preparation.

\section{Preparation of $\mathrm{ABS}$}

Antibacterial substance produced by $B$. velezensis BUU004 was prepared into two forms, concentrated supernatant and partially purified substance. To produce the concentrated supernatant, the CFS from $B$. velezensis BUU004 was 5-fold concentrated using a rotary evaporator (Rotavapor R-215, Buchi, Switzerland) at $150 \mathrm{mbar}$ and $45-50^{\circ} \mathrm{C}$ prior to being passed through a $0.45 \mu \mathrm{m}$ filter (Sartorius, Germany) and stored at $4{ }^{\circ} \mathrm{C}^{17}$. The concentrated supernatant produced by B. velezensis BUU004 was designated as CBV. Partially purified substance was prepared according to previous procedure ${ }^{18}$ with some modifications. The CFS obtained from B. velezensis BUU004 was added with ammonium sulphate at $80 \%$ saturation to precipitate protein and stirred gently at $4^{\circ} \mathrm{C}$ overnight. Precipitates were collected by centrifugation (Centrifuge 5804 $\mathrm{R}$, Eppendorf, Germany) at $10000 \mathrm{~g}, 4^{\circ} \mathrm{C}$ for $30 \mathrm{~min}$, re-suspended in $50 \mathrm{mM}$ sodium phosphate buffer solution (PBS; $\mathrm{NaH}_{2} \mathrm{PO}_{4}(7.742 \mathrm{~g})$ and $\mathrm{Na}_{2} \mathrm{PHO}_{4} \cdot 7 \mathrm{H}_{2} \mathrm{O}(2.914 \mathrm{~g})$ in 1-1 deionized water, $\mathrm{pH}$ 7.0), and then dialysed using a dialysis membrane (cutoff $1 \mathrm{kDa}$, Spectrum Laboratory, USA) at $4{ }^{\circ} \mathrm{C}$ overnight. The partially purified substance prepared from B. velezensis BUU004 was filtered using a $0.45 \mu \mathrm{m}$ filter (Sartorius) and designated as PBV. 
Antibacterial activity of the CBV and PBV was evaluated against $B$. cereus TISTR 687, an indicator strain, using agar well diffusion method and expressed as activity unit (AU)/ml. Activity unit was defined as the reciprocal of the highest dilution that produced an inhibition zone against indicator bacteria and calculated based on the equation $2^{n} / V \times 1000(\mu l)$, where $n$ is the reciprocal of the highest dilution that give inhibition zone against the indicator strain and $V$ is volume of each dilution added into the wells ${ }^{18}$. Antibacterial activity of the CBV and PBV in this study was 400 and $800 \mathrm{AU} / \mathrm{ml}$, respectively (data not shown).

\section{Antibacterial efficiency of CBV and PBV in dried seafood model}

To investigate antibacterial potentials of CBV and PBV against pathogens in dried seafood, crushed dried seasoned squid product was selected as a food model because of high TVC observed in bacteriological surveys in this study and previous reports 4,5 and its specific properties that allow ABS solution to easily absorb into the dried squid matrix. Four pathogenic bacteria, B. cereus TISTR 687, S. aureus ATCC 25923, S. Typhimurium TISTR 292 and E. coli ATCC 25922 were experimentally inoculated into crushed dried seasoned squids. These foodborne pathogens were selected in this study because they were frequently found in dried seafood products and associated with foodborne illness in Thailand ${ }^{4,19}$. Cell suspension of each pathogen was prepared $^{20}$. Each bacterium was subcultured in 10$\mathrm{ml}$ TSB (BD Difco) and incubated at $37^{\circ} \mathrm{C}$ for 18 $20 \mathrm{~h}$ to reach a stationary growth phase. Bacterial cultures were centrifuged at $8000 \mathrm{~g}$ for $10 \mathrm{~min}$ at $4{ }^{\circ} \mathrm{C}$, then washed three-time and re-suspended in PBS ( $\mathrm{pH}$ 7.2). Bacterial cell concentration was adjusted to $10^{4} \mathrm{CFU} / \mathrm{ml}$. Crushed dried seasoned squids were aseptically cut to $2 \mathrm{~cm} \times 2 \mathrm{~cm}$ pieces with approximately weight of $0.3-0.5 \mathrm{~g}$ per piece. A $4 \mathrm{~cm}^{2}$ piece sample was introduced with one of the four pathogen suspensions to produce a final concentration of $10^{4} \mathrm{CFU} / \mathrm{g}$ and, then air-dried in a biosafety cabinet for $10 \mathrm{~min}$.

Dried squid samples inoculated with each pathogen suspension were divided to five portions to introduce with a small volume $(0.1 \mathrm{ml})$ of one of these supplements: (1) CBV (400 AU/ml), (2) PBV (800 AU/ml), (3) nisin (1000 IU/ml), (4) lactic acid ( $5 \mathrm{mM})$, and (5) sterile distilled water (control) prior to being air-dried for $15 \mathrm{~min}$. Nisin and lactic acid were used in the present study as commercial preservative indicators. Pathogen numbers in dried squid samples were monitored immediately after inoculation, $1 \mathrm{~h}$ and $7,14,21$, and 28 d poststorage in a $4^{\circ} \mathrm{C}$ refrigerator using MPN technique as aforementioned for $S$. aureus ATCC 25923 and E. coli ATCC 25922. To enumerate B. cereus TISTR 687, a three-tube MPN technique was applied following the US FDA's BAM protocol ${ }^{12}$. Dried squid samples were serially diluted with BPW. A small volume $(1 \mathrm{ml})$ from each dilution was inoculated into a series of three tubes containing TSB supplemented with $0.1 \%$ polymyxin sulphate. After incubation at $30 \pm 2{ }^{\circ} \mathrm{C}$ for $48 \mathrm{~h}$, all turbid tubes were subcultured onto Mannitol Egg Yolk Polymyxin agar (BD Difco) and incubated at $30^{\circ} \mathrm{C}$ for $18-24 \mathrm{~h}$. Suspicious colonies (pink colonies surrounded by precipitate zone of lecithinase activity) were confirmed by selected biochemical tests: nitrate reduction, tyrosine decompose test and growth in lysozyme broth. A three-tube three-dilution MPN method was used to count $S$. Typhimurium TISTR 292 numbers as previously described ${ }^{21}$ with slight modification. Dried squid samples were 10-fold diluted in three sets of three tubes containing lactose broth and incubated at $37^{\circ} \mathrm{C}$ for $24 \mathrm{~h}$. Then a $1-\mathrm{ml}$ aliquot was transferred to 10 -ml TT broth and incubated at $42^{\circ} \mathrm{C}$ for $24 \mathrm{~h}$. Afterwards, a loopful of the TT broth was streaked on Hektoen Enteric Agar plates and incubated at $37^{\circ} \mathrm{C}$ for $24 \mathrm{~h}$. Salmonella colonies (blue-green to blue colonies with or without black centres) were subjected to biochemical testing ${ }^{12}$. The MPN tables were used to calculate the approximate number of bacteria per gram.

\section{Observation of pore formation by scanning electron microscopy}

To study bacteriostatic activity against foodborne pathogens of PBV prepared from B. velezensis BUU004, bacterial cells of all pathogens used in this study were prepared for scanning electron microscopy observation ${ }^{10}$. Briefly, each pathogen (B. cereus TISTR 687, S. aureus ATCC 25923, S. Typhimurium TISTR 292 and E. coli ATCC 25922) was grown in TSB at $30^{\circ} \mathrm{C}$ for $10-15 \mathrm{~h}$ to attain a midexponential growth phase. Afterwards, cell pellets were harvested by centrifuging 1-ml cell suspension at $8000 \mathrm{~g}, 4^{\circ} \mathrm{C}$ for $15 \mathrm{~min}$. An aliquot $(1 \mathrm{ml})$ of $\mathrm{PBV}$ at $800 \mathrm{AU} / \mathrm{ml}$ was added in a tube containing cell pellets of each pathogen at approximately $10^{8}$ $\mathrm{CFU} / \mathrm{ml}$. Cell pellets added with TSB $(1 \mathrm{ml})$ was considered as the negative control. After incubation at $37^{\circ} \mathrm{C}$ for $24 \mathrm{~h}$, cell suspensions were washed twice with PBS (pH 7.2), then harvested by centrifugation $\left(6000 \mathrm{~g}, 4^{\circ} \mathrm{C}\right.$ for $\left.10 \mathrm{~min}\right)$. Collected cell pellets 
were adhered on a coated glass slide, air-dried for $2 \mathrm{~h}$, and pre-fixed using 2\% glutaraldehyde in PBS (pH 7.2) overnight at $4{ }^{\circ} \mathrm{C}^{22}$. Subsequently, cells were post-fixed with $1 \%(\mathrm{v} / \mathrm{v})$ osmium tetroxide for $2 \mathrm{~h}$, and washed three-time with PBS (pH 7.2). Fixed cells were dehydrated in ethanol gradients (20\%, 50\%, 70\%, 80\%, 90\%, and $100 \%$, respectively) for $15 \mathrm{~min}$ for each step at $25^{\circ} \mathrm{C}$. Ethanol was replaced with isoamyl acetate for 10 min twotime. Cells were then dried in a critical point dryer (Polaron Range SC 7501, Quorum Technologies, UK) for $1 \mathrm{~h}$ using liquid $\mathrm{CO}_{2}$ as an intermedium. Dried cells were coated with gold in an ion sputter coater (Polaron Range SC 7620, Quorum Technologies, UK). Photomicrographs of cell damages were examined under a scanning electron microscope (SEM; LEO 1450 VP, ZEISS, Germany) equipped with an SEM User Interface, LEO-32 software.

\section{Statistical analysis}

All measurements were performed in triplicate. Data were presented as mean \pm SD. The MPN values with $95 \%$ confidence intervals were used as described in appendix 2 of the US FDA's Bacteriological Analytical Manual ${ }^{12}$.

\section{RESULTS AND DISCUSSION}

\section{Intrinsic properties of dried seafood products}

Table 1 showed the values of $a_{\mathrm{w}}, \mathrm{pH}$ and $\mathrm{NaCl}$ concentration in all dried seafood samples distributed in Chon Buri, Thailand. Level of $a_{\mathrm{w}}$ in dried seafood samples was $0.35 \pm 0.01-0.72 \pm 0.00$. Most dried seafood products had a narrow acidic range of $\mathrm{pH}$ value from $5.47 \pm 0.03-6.86 \pm 0.15$. However, $\mathrm{pH}$ value of crispy seasoned fish products was higher than that observed in other products in the range of $6.33 \pm 0.07-9.24 \pm 0.01$. NaCl contents in dried seafood samples were between $0.66 \pm 0.07$ and $2.26 \pm 0.03 \%$. A wide variation in $\mathrm{NaCl}$ content in each sample was observed in most product types, except dried squids (Table 1). Our re- sults were consistent with a report by Thungkao and Muangharm ${ }^{4}$, who found that dried seasoned squids sold in Thailand had low $a_{\mathrm{w}}(0.52-0.72), \mathrm{pH}$ value (6.06-6.34) and $\mathrm{NaCl}$ content (3.19-3.72\%). Proportion of unacceptable dried seafood products was 30\% (6/20) including crushed dried seasoned squids (4) and sweet dried squid crisps (2) based on $a_{\mathrm{w}}$ value following Thai regulatory standard of 0.86 for processed products and 0.6 for cooked ready-toeat products, respectively ${ }^{23}$.

\section{Bacteriological quality of dried seafood products}

Total viable counts in dried seafood products were in the range of $10^{1}-10^{9} \mathrm{CFU} / \mathrm{g}$ (Table 2). Some dried seafood samples contained very high TVC; two samples each of dried fish and dried squids $\left(10^{7}\right.$ $10^{8} \mathrm{CFU} / \mathrm{g}$ ) and one crushed dried seasoned squid sample $\left(10^{9} \mathrm{CFU} / \mathrm{g}\right)$. Of 20 dried seafood samples, TVC exceeded the allowable level of $5 \times 10^{4} \mathrm{CFU} / \mathrm{g}$ for processed products and $5 \times 10^{5} \mathrm{CFU} / \mathrm{g}$ for cooked ready-to-eat products imposed by Department of Fisheries $^{24}$ in 10 samples (50\%, Table 2); dried fish (2), dried squids (4), crispy seasoned fish (1), and crushed dried seasoned squids (3). All sweet dried squid crisp samples contained TVC below the acceptable limit of Thai regulatory standard. The unacceptable percentages observed in our results coincided with previous reports focused on biosafety of traditional dried seafood products in Thailand over the last decade in the range of $36.7-51.8 \%{ }^{4,5}$.

Although dried seafood products in our study contained low $a_{\mathrm{w}}(0.35 \pm 0.01-0.72 \pm 0.00)$, which was lower than a minimum level for bacterial growth $\left(a_{\mathrm{w}}<0.85\right)$, a total of 73 bacterial isolates were recovered (Table 3 ) and identified as $B$. cereus, B. coagulans, B. firmus, B. laterosporus, B. licheniformis, Listeria ivanovii, S. caprae, S. epidermidis, S. hominis, Bordetella holomesii, Burkholderia cepacia and Pantoea spp. Their survivability in dried seafood products may reflect a high tolerance under

Table 1 Intrinsic properties of dried squid products collected from local market in Chon Buri, Thailand.

\begin{tabular}{lcccc}
\hline Dried seafood product type & No. of sample & Water activity $\left(a_{\mathrm{w}}\right)$ & $\mathrm{pH}$ & $\mathrm{NaCl}$ content $(\%)$ \\
\hline $\begin{array}{l}\text { Processed products }{ }^{\mathrm{a}} \\
\text { Dried fish }\end{array}$ & 4 & $0.59 \pm 0.00-0.65 \pm 0.00$ & $6.22 \pm 0.04-6.37 \pm 0.06$ & $0.66 \pm 0.07-2.26 \pm 0.02$ \\
Dried squids & 4 & $0.61 \pm 0.02-0.71 \pm 0.01$ & $6.39 \pm 0.02-6.63 \pm 0.00$ & $2.16 \pm 0.05-2.26 \pm 0.03$ \\
\hline Cooked ready-to-eat products & & & & \\
Crispy seasoned fish & 4 & $0.35 \pm 0.01-0.55 \pm 0.00$ & $6.33 \pm 0.07-9.24 \pm 0.01$ & $0.93 \pm 0.03-1.79 \pm 0.02$ \\
Crushed dried seasoned squids & 4 & $0.62 \pm 0.00-0.72 \pm 0.00$ & $5.47 \pm 0.03-6.86 \pm 0.01$ & $0.66 \pm 0.06-2.24 \pm 0.03$ \\
Sweet dried squid crisps & 4 & $0.50 \pm 0.00-0.63 \pm 0.00$ & $5.60 \pm 0.03-6.86 \pm 0.15$ & $0.78 \pm 0.02-2.00 \pm 0.08$ \\
\hline
\end{tabular}

\footnotetext{
${ }^{\text {a }}$ Processed products means dried seafood that need minimum heating before consumption.

${ }^{\mathrm{b}}$ Cooked ready-to-eat products means dried seafood without cooking before consumption.
} 
Table 2 Number of total viable bacteria in dried seafood products collected from local market in Chon Buri, Thailand.

\begin{tabular}{|c|c|c|c|c|c|c|}
\hline \multirow{2}{*}{ Dried seafood products } & \multicolumn{5}{|c|}{ No. of samples with count (CFU/g) } & \multirow{2}{*}{$\begin{array}{l}\text { No. of sample/No. of } \\
\text { unacceptable sample }\end{array}$} \\
\hline & $10-5 \times 10^{4}$ & $>5 \times 10^{4}-5 \times 10^{5}$ & $>5 \times 10^{5}-10^{6}$ & $10^{7}-10^{8}$ & $10^{9}$ & \\
\hline \multicolumn{7}{|l|}{ Processed products ${ }^{\mathrm{a}}$} \\
\hline Dried fish & 2 & 0 & 0 & 2 & 0 & $4 / 2$ \\
\hline Dried squids & 0 & 0 & 2 & 2 & 0 & $4 / 4$ \\
\hline \multicolumn{7}{|l|}{ Cooked ready-to-eat products ${ }^{\mathrm{b}}$} \\
\hline Crispy seasoned fish & 3 & 0 & 1 & 0 & 0 & $4 / 1$ \\
\hline Crushed dried seasoned squids & 1 & 2 & 0 & 0 & 1 & $4 / 3$ \\
\hline Sweet dried squid crisps & 4 & 0 & 0 & 0 & 0 & $4 / 0$ \\
\hline
\end{tabular}

${ }^{a}$ Processed products mean dried seafood that need minimum heating before consumption.

${ }^{\mathrm{b}}$ Cooked ready-to-eat products mean dried seafood without cooking before consumption.

${ }^{c}$ According to the Thai microbiological standard for fishery food regulated under Department of Fisheries, Thailand ${ }^{24}$, acceptable limits of bacteria in processed and cooked ready-to-eat products are not exceeded $5 \times 10^{5}$ and $5 \times$ $10^{4} \mathrm{CFU} / \mathrm{g}$, respectively.

Table 3 Prevalence of various bacteria in dried seafood products collected from local market Chon Buri, Thailand.

\begin{tabular}{|c|c|c|c|c|c|c|c|c|c|c|c|c|c|c|}
\hline \multirow{2}{*}{ Dried seafood product type } & \multicolumn{14}{|c|}{ Bacterial species $^{\mathrm{a}}$} \\
\hline & 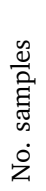 & 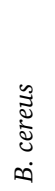 & 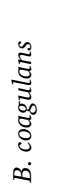 & $\sum_{\infty}^{\stackrel{\Xi}{E}}$ & 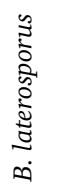 & 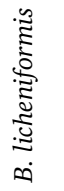 & 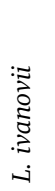 & 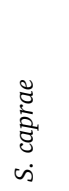 & 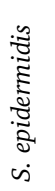 & 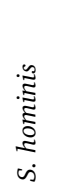 & 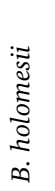 & 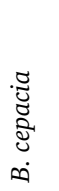 & 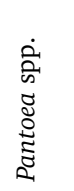 & 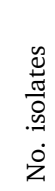 \\
\hline \multicolumn{15}{|l|}{ Processed products ${ }^{\mathrm{b}}$} \\
\hline Dried fish & 4 & 1 & 1 & - & 2 & 1 & 3 & 3 & 1 & 2 & - & - & 3 & 17 \\
\hline Dried squids & 4 & - & 2 & - & - & - & - & 3 & - & 4 & 1 & 1 & 4 & 15 \\
\hline \multicolumn{15}{|l|}{ Cooked ready-to-eat products ${ }^{c}$} \\
\hline Crispy seasoned fish & 4 & - & 2 & 1 & 2 & 3 & 1 & 3 & 1 & 1 & - & - & 3 & 17 \\
\hline Crushed dried seasoned squids & 4 & 1 & - & - & 1 & - & 1 & 4 & 1 & 1 & - & - & 2 & 11 \\
\hline Sweet dried squid crisps & 4 & 1 & - & 1 & 1 & 2 & 1 & 3 & 1 & 1 & - & - & 2 & 13 \\
\hline Total isolates & & 3 & 5 & 2 & 6 & 6 & 6 & 16 & 4 & 9 & 1 & 1 & 14 & 73 \\
\hline Percentage (\%) & & 4.1 & 6.9 & 2.7 & 8.2 & 8.2 & 8.2 & 21.9 & 5.5 & 12.3 & 1.4 & 1.4 & 19.2 & 100 \\
\hline
\end{tabular}

${ }^{\text {a }}$ Various bacterial species recovered from dried seafood products.

${ }^{\mathrm{b}}$ Processed products mean dried seafood that need minimum heating before consumption.

${ }^{c}$ Cooked ready-to-eat products mean dried seafood without cooking before consumption.

harsh conditions such as low moisture content and desiccation. The most predominant viable bacteria in dried seafood products were Staphylococcus spp. (39.7\%), followed by Bacillus spp. (30.1\%) and Pantoea spp. (19.2\%), respectively. This result agreed with previous report on bacterial flora in seasoned fish products collected from the retail markets in Korea which were composed mainly of Staphylococcus spp. (33.8\%), Bacillus spp. (15.2\%) and coliforms $(13.3 \%)^{25}$. Due to its human and environmental origins, the presence of Staphylococcus as a main bacterial constituent in dried seafood products in this study is possibly associated with poor personnel hygiene in preparation and production processes ${ }^{26}$. Twenty-two Bacillus isolates (30.1\%) were found in all types of dried seafood products. They may contaminate into the products via spices, i.e., peppers, chilies and other food additives during production processes ${ }^{27}$. Bacillus spp. are also ubiquitous in a variety of habitats, e.g., soil, dust, aquatic environments, foods and gastrointestinal tracts of several insects and animals ${ }^{7}$. Bacillus spp. produce durable endospores whose ability may be helpful to survive and contaminate in food products during food production, transportation, and storage ${ }^{27}$. Importantly, three isolates of $B$. cereus, a foodborne pathogen causing diarrhoea and emetic illness, were recovered from three dried seafood samples (15\%, 3/20): dried fish, crushed dried seasoned squids and sweet dried squid crisps. Thungkao and Muangharm ${ }^{4}$ reported $B$. cereus prevalence of $61.1 \%$ in dried seasoned squid products. According to previous report, $B$. cereus was found in dried squids, dried fishes and dried pollack in Korea with a prevalence level of $9.1 \%{ }^{25}$. In this study, Pantoea spp., a Gramnegative bacilli of the family Enterobacteriaceae, was 
also found to be prevalent in dried seafood products (19.2\%). Ivrsen and Forsythe ${ }^{28}$ reported dried food products $(5.4 \%)$ collected from retailers across the UK contaminated with Pantoea spp. Due to its wide range of habitats including human, plants, water, soil, and animals ${ }^{29}$, poor hygiene practices, prolonged exposure to air during drying process and bulk stock in plastic bags without suitable packaging are likely to be possible reason for the contamination.

Following a bacteriological regulatory standard implemented by Department of Fisheries ${ }^{24}$, E. coli contaminated in cooked ready-to-eat and processed seafood products must not be exceeded 3.6 and $10 \mathrm{MPN} / \mathrm{g}$. All dried seafood products contained E. coli number below the standard except that (4 $\mathrm{MPN} / \mathrm{g}$ ) observed in one dried squid sample. It is well known that $E$. coli is used as an indicator of fecal contamination. Its contamination in food commodities can cause foodborne illnesses associated with diarrhoea or extraintestinal diseases ${ }^{30}$. Of 20 dried seafood products, one dried squid sample $(5 \%)$ was unacceptable following Thai regulatory standard in terms of bacteriological quality due to contamination with Salmonella enterica serovar Weltevreden. A few reports confirmed that Salmonella was able to survive at least a year in foodstuffs containing an extremely low $a_{\mathrm{w}}$ of $0.30-0.52$, such as chocolate, dried milk products, dried fish and egg powder ${ }^{31}$. Occurrence of Salmonella may be associated with inadequate preservation, poor personal hygiene and post-process contamination ${ }^{32}$. In the present study, S. aureus was absent $(<3 \mathrm{MPN} / \mathrm{g})$ in all dried seafood products.

This study here confirms the fact that dried squid products have confronted with a significant risk of food safety and are necessary to control the bacterial contamination to avoid the health problems of consumers and comply with dried seafood standard. Hence good manufacturing practices, viz., good hygiene practices, good manufacturing practices and hazard analysis critical control point systems should be established in the facilities to prevent outbreaks of foodborne illness. In addition to best management approaches during production processes, it is imperative to enforce existing regulations that designate microbiological quality of food products and food safety managements required in the factories. Furthermore, public educational campaigns should also be promoted to create biosafety awareness in dried seafood products of the factory personnel and consumers.

\section{Antibacterial efficiency of CBV and PBV in dried seafood model}

Despite growth limitation of most bacteria by reducing an amount of water available, foodborne pathogens have become a threat to biosafety of dried seafood products in Thailand and other countries $^{33,34}$. In addition to management approaches mentioned above, development of a novel technology is required to enhance seafood product safety and organoleptic quality. In the present study, inhibitory effect of the two ABS forms prepared from B. velezensis BUU004 (CBV and PBV) on foodborne pathogens, B. cereus TISTR 687, S. aureus ATCC 25923, S. Typhimurium TISTR 292, and E. coli ATCC 25922 was investigated in crushed dried seasoned squids and compared to two commercial preservatives (nisin and lactic acid).

Changes in pathogen numbers in crushed dried seasoned squids added with different supplements during a 28 -d storage at $4{ }^{\circ} \mathrm{C}$ were shown in Fig. 1 . Nisin showed the strongest antibacterial effect on B. cereus TISTR 687 in dried squids. It took a short period of exposure time (1 h post-exposure) to reduce number of $B$. cereus TISTR 687 from $>1100$ to $23 \mathrm{MPN} / \mathrm{g}$ and this pathogen number continuously decreased to $3.6 \mathrm{MPN} / \mathrm{g}$ at the end of storage (Fig. 1a). Inhibitory activity against $B$. cereus TISTR 687 of PBV in dried squids was relatively similar to that of CBV. In both treatments, B. cereus TISTR 687 number markedly decreased to $75 \mathrm{MPN} / \mathrm{g}$ and $43 \mathrm{MPN} / \mathrm{g}$, respectively, at $1 \mathrm{~h}$ post-exposure, then dramatically dropped to non-detectable level $(<3$ $\mathrm{MPN} / \mathrm{g}$ ) and $3 \mathrm{MPN} / \mathrm{g}$ at $28 \mathrm{~d}$ post-storage, respectively (Fig. 1a). On the contrary, lactic acid had no inhibitory effect on $B$. cereus TISTR 687 owing to similar pathogen number found throughout 28-d storage in comparison with the control.

Inhibitory activities of PBV and CBV against S. aureus ATCC 25923 in dried squids were comparatively similar (Fig. 1b). In both groups, pathogen numbers declined to $23 \mathrm{MPN} / \mathrm{g}$ at $7 \mathrm{~d}$ post-storage and decreased over time until reaching 9.2 and 14 $\mathrm{MPN} / \mathrm{g}$, respectively, at the end of storage. Meanwhile, nisin showed low effectiveness in inhibition of $S$. aureus ATCC 25923 in dried squids because of higher $S$. aureus number ranging from 93-23 MPN/g observed during a 28-d storage (Fig. 1b).

Addition of PBV in S. Typhimurium TISTR 292challenged dried squids exhibited moderate growth inhibition. Number of viable $S$. Typhimurium TISTR 292 cells slowly decreased from $>1100$ to 23 MPN/g after 28-d storage (Fig. 1c). However, CBV, 


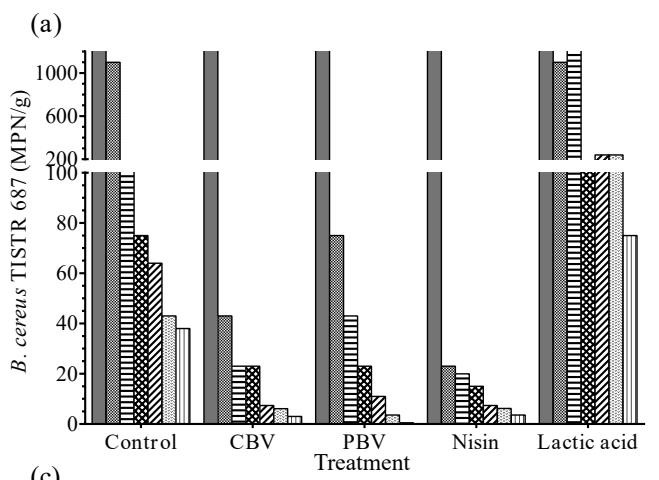

(b)
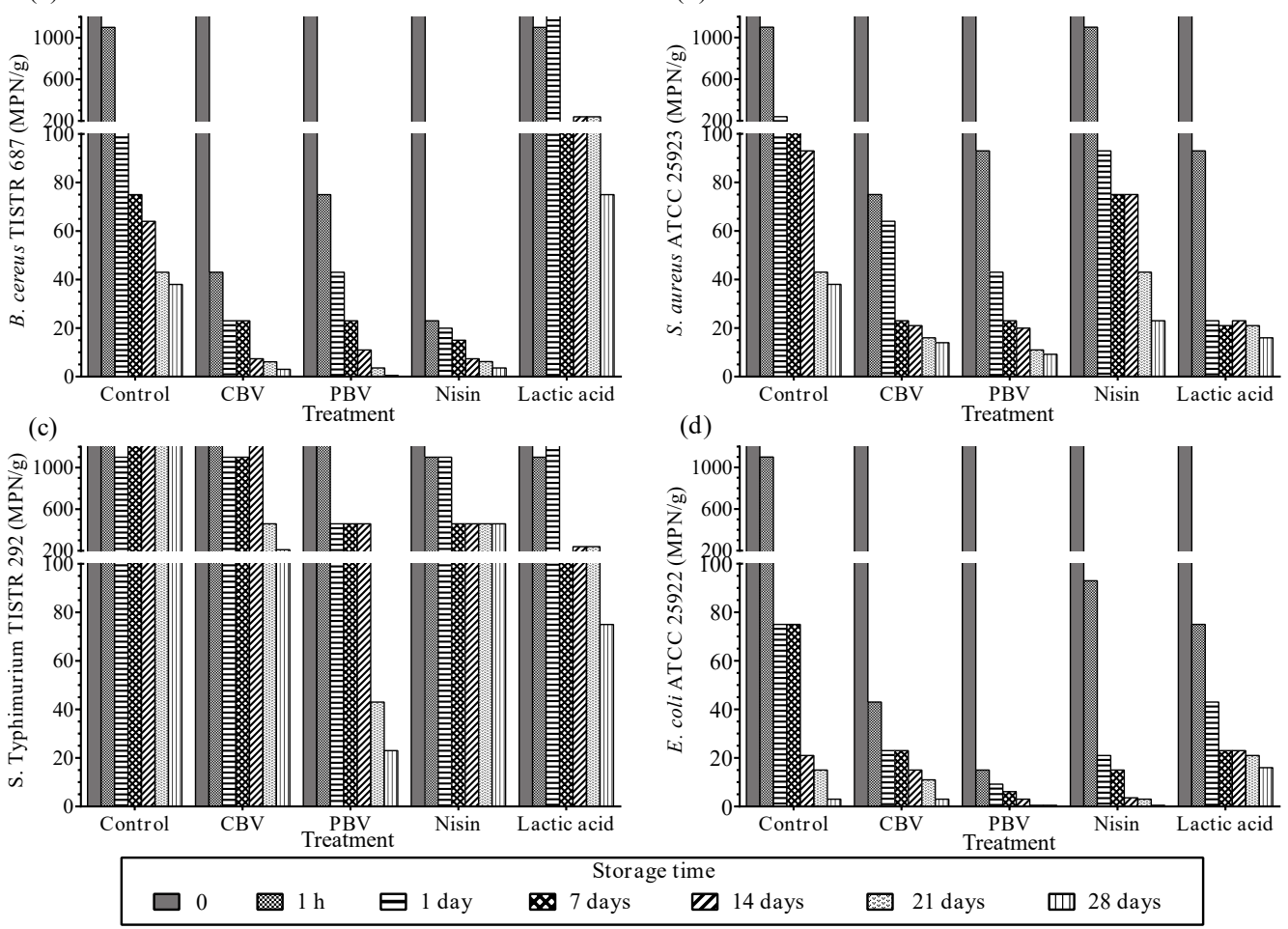

Fig. 1 Pathogen dynamics (MPN/g) in dried seasoned squid samples supplemented with concentrated supernatant or partially purified substance produced by B. velezensis BUU004 in comparison with commercial preservatives (nisin and lactic acid) during a 28-d storage at $4^{\circ} \mathrm{C}$. (a) B. cereus TISTR 687, (b) S. aureus ATCC 25923, (c) S. Typhimurium TISTR 292, (d) E. coli ATCC 25922; Control = sterile distilled water; CBV = concentrated supernatant from B. velezensis BUU004; PBV = partially purified substance from $B$. velezensis $\mathrm{BUU004}$; nisin $=1000 \mathrm{IU} / \mathrm{ml}$ nisin; lactic acid $=5 \mathrm{mM}$ lactic acid.

nisin and lactic acid seemed to have very low inhibitory activity because of high $S$. Typhimurium TISTR 292 number (75-> $1100 \mathrm{MPN} / \mathrm{g}$ ) observed during a 28-d storage (Fig. 1c).

Number of E. coli ATCC 25922 in the control group at the beginning of experiment was $>1100$ $\mathrm{MPN} / \mathrm{g}$ and remained high at $1 \mathrm{~h}$ post-exposure (Fig. 1d). In contrast, number of E. coli ATCC 25922 rapidly diminished from $>1100$ to $15 \mathrm{MPN} / \mathrm{g}$ at $1 \mathrm{~h}$ post-exposure and continuously reduced to nondetectable level $(<3 \mathrm{MPN} / \mathrm{g})$ at 21-d storage when exposed to PBV. Similar moderate activity was observed when CBV or nisin was added by which E. coli ATCC 25922 numbers decreased to 43 and $93 \mathrm{MPN} / \mathrm{g}$, respectively, at $1 \mathrm{~h}$ post-exposure and to $3 \mathrm{MPN} / \mathrm{g}$ at the end of storage (Fig. 1d).

Our results clearly demonstrated that PBV had a wider inhibitory spectrum than CBV against growth of both Gram-positive (B. cereus TISTR 687 and S. aureus ATCC 25923) and Gram-negative bacteria (S. Typhimurium TISTR 292 and E. coli ATCC
25922). A broad inhibitory spectrum has been reported in ABS produced by B. amyloliquefaciens An6 against $E$. coli, $S$. Typhimurium, B. cereus, S. aureus and Micrococcus luteus ${ }^{35}$.

Despite nisin containing high potency against many bacteria, especially Gram-positive bacteria ${ }^{36}$, one such limitation reason to use nisin as a natural preservative in food market is because of their narrow inhibitory spectrum with weak activity against Gram-negative bacteria as observed in our results and other reports ${ }^{8}$. Hence a wide antagonistic range of PBV against certain foodborne bacteria demonstrates that PBV has potential to be an alternative preservative to replace a narrow-spectrum nisin. To use PBV as a preservative in dried seafood products, further studies should be performed including the risk assessment of bacterial contamination in each step during the dried crushed squid preparation and production, and inhibitory activity of the PBV against foodborne pathogens to generate information of when our substance should be in- 
corporated into the products without degenerative effects and to achieve the highest inhibitory efficacy.

In general, broth supernatants from Bacillus genera contain a variety of peptides, enzymes and unknown substances. Although actual antibacterial agent in PBV against the four foodborne bacteria in this study is still unknown at this stage, such hypothesis is that inhibitory effects may have been associated with bacteriocins or bacteriocin-like inhibitory substances. In our preliminary study, PBV prepared from $B$. velezensis BUU004 was proven to have antimicrobial peptide. B. velezensis has been reported to produce a vast array of biologically active molecules potentially inhibitory of pathogenic microbes, such as polyketides, lipopeptides and bacteriocins ${ }^{37}$. Similarly, B. velezensis FZB42, formerly known as $B$. amyloliquefaciens, was found to produce a circular bacteriocin, viz., amylocyclicin and plantazolicin, which displayed high antibacterial activity against closely related Gram-positive bacteria, e.g., Bacillus spp., Paenibacillus spp. and M. luteus, but no activity towards Gram-negative bacteria $^{38}$. Interestingly, PBV prepared from B. velezensis BUU004 in our study may contain a novel antimicrobial peptide produced by this bacterial species due to a wider range of inhibitory activity. Hence profound characterization of this PBV prepared from $B$. velezensis BUU004 should be further established to explain why numbers of all four pathogens in this study substantially decreased in crushed dried squid product.

\section{Pore formation induced by PBV}

To investigate inhibitory activity noticed in dried seafood model, morphological changes of the four foodborne bacterial cells exposed to PBV were observed through SEM (Fig. 2). Untreated cells of all four pathogens exhibited a normal cell shape with smooth and intact in appearance (Fig. 2a1, b1, c1, and $\mathrm{d} 1$ ). In contrast, all PBV-treated pathogenic bacteria had severe cell membrane deconstructions evidenced by irregular cell shape with wrinkles on their surfaces (Fig. 2a2, b2, c2, and d2) along with aggregation of damaged cells and/or cellular debris. Shrinking cells with corrugated surfaces were also seen in PBV-exposed bacteria which may result from the leakage and release of cytoplasmic fluids through pores formed on their cells (Fig. 2a2, $\mathrm{b} 2, \mathrm{c} 2$, and $\mathrm{d} 2$ ). This study indicated that PBV had a bacteriostatic activity against both foodborne Gram-positive and Gram-negative bacteria via cell lysis as a mode of action. In general, the mode of action of antimicrobial peptides produced by

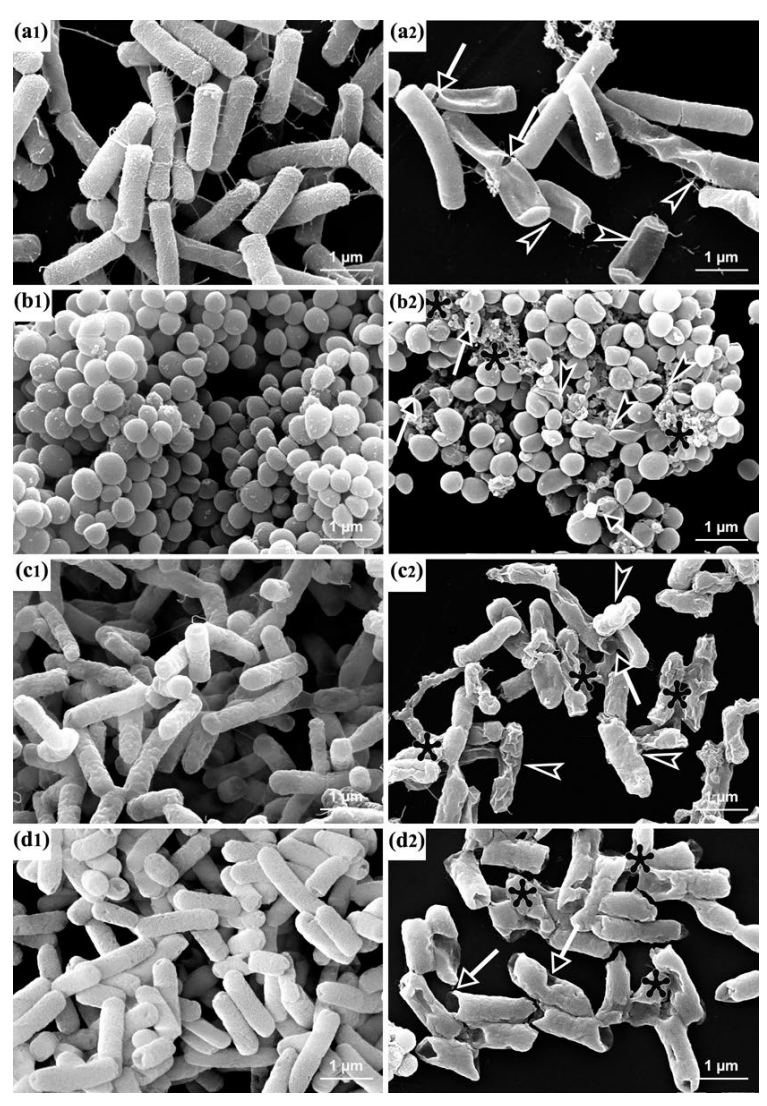

Fig. 2 SEM images of the four pathogenic bacteria treated with or without PBV for $24 \mathrm{~h}$. (a1) normal appearance of PBV-unexposed B. cereus TISTR 687 cells; (a2) irregular shape of PBV-treated B. cereus TISTR 687 cells (arrowhead) along with pore formation (arrow); (b1) intact cells of PBV-unexposed S. aureus ATCC 25923; (b2) distorted PBV-treated S. aureus ATCC 25923 cells (arrowhead) concomitant with pore formation (arrow) and agglutination of intracellular debris (asterisk); (c1) undamaged morphological structure of PBV-unexposed $S$. Typhimurium TISTR 292; (c2) pore formation (arrow), and severe shrinkage and corrugated surfaces (arrowhead) together with aggregation (asterisk) of PBV-treated S. Typhimurium TISTR 292 cells; (d1) smooth cell surfaces of PBV-unexposed E. coli ATCC 25922; (d2) severely abnormal shape of PBV-treated E. coli ATCC 25922 cells with pore formation (arrow) and aggregation of damaged cells (asterisk).

Bacillus genera includes destabilizing the cellular structure, destroying membrane integrity, increasing membrane permeability, and disrupting cellular activities, e.g., energy production and membrane transport ${ }^{39}$. Formation of pores on bacterial cells in this study may be possibly due to conformation 
change at the membrane after which lipid bilayers were exposed to PBV, thereby dissipating the membrane potential and eventually cell death. Other modes of action of PBV, e.g., biofilm destruction and membrane permeabilization, need to be further investigated to understand how this biocontrol agent interacts with pathogens, which would facilitate to design an efficacious application strategy.

\section{CONCLUSIONS}

In the present study, Thai dried seafood products distributed in Chon Buri province contained values of $a_{\mathrm{w}}, \mathrm{pH}$ and $\mathrm{NaCl}$ content in the range of $0.35 \pm 0.01-0.72 \pm 0.00,5.47 \pm 0.03-$ $9.24 \pm 0.01$, and $0.66 \pm 0.06-2.26 \pm 0.03 \%$, respectively. Total viable count in dried seafood products ranged from $10^{1}-10^{9} \mathrm{CFU} / \mathrm{g}$. Of 20 samples, there were $50 \%$ of dried seafood samples did not meet the Thai regulatory standard of dried seafood biosafety. The most frequently isolated bacteria in dried seafood products were Staphylococcus spp. (39.7\%), followed by Bacillus spp. (30.1\%) and Pantoea spp. (19.2\%). B. cereus was recovered from dried fish, crushed dried seasoned squids and sweet dried squid crisps. One dried squid sample (5\%) was contaminated with $S$. enterica serovar Weltevreden. Dried seafood products harboured E. coli and $S$. aureus numbers within acceptable values imposed by Department of Fisheries, Thailand. Due to high unacceptable percentages of dried seafood products observed in this study, we introduced two forms of ABS produced by B. velezensis BUU004 (CBV and PBV) into crushed dried seasoned squids used as a food model to control growths of foodborne pathogens; B. cereus TISTR 687, S. aureus ATCC 25923, S. Typhimurium TISTR 292, and E. coli ATCC 25922. Our study revealed that PBV showed a broader antibacterial activity against all tested foodborne pathogens in dried seasoned squids than $\mathrm{CBV}$ and commercial preservatives (nisin and lactic acid). Clearly, bacteriostatic action of PBV against all tested pathogens was cell lysis strongly supported by severe cell membrane deconstruction and pore formation observed through SEM. The present study suggests that PBV prepared from $B$. velezensis BUU004 is an appropriate alternative to replace other synthetic food preservatives for controlling foodborne bacterial growth and improving quality of Thai dried seafood products. However, this is preliminary investigation of its preservative potential in dried seafood products. Additional studies should be further conducted including characterization of the active components in PBV prepared from
B. velezensis BUU004 and assessment of its biosafety to ensure the appropriate use before being approved for human consumption.

Acknowledgements: This study was financially supported by the Royal Golden Jubilee PhD Programme of Thailand Research Fund (No. PHD/0370/2552) to Nimrat S. and Butkhot N. and the Research Grant of Burapha University through National Research Council of Thailand (No. 65/2557) and (No. 66/2558) to Nimrat S. The authors are grateful to Faculty of Science, Burapha University, Thailand, for providing equipments and facilities.

\section{REFERENCES}

1. Fisheries Development Policy and Strategy Division (2017) Fisheries Trade Statistics of Thailand 2017, Department of Fisheries, Bangkok, pp 131-180.

2. Bellagha S, Sahli A, Farhat A, Kechaou N, Glenza A (2007) Studies on salting and drying of sardine (Sardinella aurita): Experimental kinetics and modeling. $J$ Food Eng 78, 947-52.

3. Fu XY, Xue CH, Miao BC, Li ZJ, Zhang YQ, Wang Q (2007) Effect of processing steps on the physicochemical properties of dried-seasoned squid. Food Chem 103, 287-94.

4. Thungkao S, Muangharm S (2008) Prevalence of Bacillus spp. and Bacillus cereus in dried seasoned squid products. In: Proceedings of the 46th Kasetsart University Annual Conference: Agro-Industry, Bangkok, pp 138-46.

5. Osiri S, Osiri P (2009) Sea food safety situation in the East. Thai J Health Promot Environ Health 32, 74-86.

6. Gálvez A, Abriouel H, López RL, Omar NB (2007) Bacteriocin-based strategies for food biopreservation. Int J Food Microbiol 120, 51-70.

7. Abriouel H, Franz CM, Omar NB, Gálvez A (2011) Diversity and applications of Bacillus bacteriocins. FEMS Microbiol Rev 35, 201-32.

8. Oulahal N, Joly C, Degraeve P (2016) Nisin as a food preservative: part 1: Physicochemical properties, antimicrobial activity, and main uses AU - Gharsallaoui, Adem. Crit Rev Food Sci Nutr 56, 1262-74.

9. Elshaghabee FMF, Rokana N, Gulhane RD, Sharma C, Panwar H (2017) Bacillus as potential probiotics: Status, concerns, and future perspectives. Front Microbiol 8, 1490.

10. Lee SG, Chang HC (2018) Purification and characterization of mejucin, a new bacteriocin produced by Bacillus subtilis SN7. LWT Food Sci Technol 87, 8-15.

11. AOAC (1995) Fish and other marine products. In: Official Methods of Analysis, 16th edn, Association of Official Analytical Chemists, Washington DC, pp 6-7.

12. US Food Drug Administration (1998) Bacteriological Analytical Manual, 8th edn, AOAC International, Gaithersburg, Maryland.

13. Whitman WB (2015) Bergey's Manual of Systematics 
of Archaea and Bacteria, Wiley Online Library, Hoboken, New Jersey.

14. Bale J, de Pinna E, Threlfall E, Ward L (2007) Kauffmann-White Scheme-2007: Salmonella Identification: Serotypes and Antigen Formulae, Centre for Infections, Health Protection Agency, London.

15. Nimrat S, Suksawat S, Maleeweach P, Vuthiphandchai V (2008) Effect of different shrimp pond bottom soil treatments on the change of physical characteristics and pathogenic bacteria in pond bottom soil. Aquacult 285, 123-9.

16. Nimrat $S$, Suksawat $S$, Boonthai T, Vuthiphandchai V (2012) Potential Bacillus probiotics enhance bacterial numbers, water quality and growth during early development of white shrimp (Litopenaeus vannamei). Vet Microbiol 159, 443-50.

17. Saeed S, Rasool SA, Ahmad S, Zaidi SZ, Rehmani S (2007) Antiviral activity of staphylococcin 188: A purified bacteriocin like inhibitory substance isolated from Staphylococcus aureus AB188. Res J Microbiol 2, 796-806.

18. An J, Zhu W, Liu Y, Zhang X, Sun L, Hong P, Yaling W, Chunhou X, et al (2015) Purification and characterization of a novel bacteriocin CAMT2 produced by Bacillus amyloliquefaciens isolated from marine fish Epinephelus areolatus. Food Control 51, 278-82.

19. Ananchaipattana C, Hosotani Y, Kawasaki S, Pongsawat S, Latiful MB, Isobe S, Inatsu Y (2012) Prevalence of foodborne pathogens in retailed foods in Thailand. Foodborne Pathog Dis 9, 835-40.

20. Kuda T, Yazaki T, Takahashi H, Kimura B (2013) Effect of dried and vinegar flavored squid products on acid resistance of Salmonella Typhimurium and Staphylococcus aureus. Food Control 30, 569-74.

21. Alali WQ, Celik C, Wu D, Cui Y, Guran HS, Mann D (2016) The relationship between Salmonella levels in chicken spleen and mechanically separated ground chicken. Food Control 66, 250-5.

22. Ullah N, Wang X, Wu J, Guo Y, Ge H, Li T, Khan S, Li $Z$, et al (2017) Purification and primary characterization of a novel bacteriocin, LiN333, from Lactobacillus casei, an isolate from a Chinese fermented food. LWT Food Sci Technol 84, 867-75.

23. Thai Industrial Standards Institute (2018) List of Thai Community Product Standards, Thai Industrial Standards Insitute, Bangkok.

24. Department of Fisheries (2009) Quality Reference Criteria, Department of Fisheries, Bangkok, pp 1-5.

25. Ham HJ, Kim SE, Ryu SH, Hwang YO, Choi SM (2010) Bacterial distributions of Escherichia coli and Bacillus cereus etc. isolated from dried seasoned marine products in Garak fishery wholesale market in Seoul, 2009. J Food Hyg Saf 25, 10-5.

26. Moon HJ, Min KJ, Park NY, Park HJ, Yoon KS (2017) Survival of Staphylococcus aureus in dried fish products as a function of temperature. Food Sci Biotechnol 26, 823-8.
27. Fogele B, Granta R, Valciņa O, Bērziņš A (2018) Occurrence and diversity of Bacillus cereus and moulds in spices and herbs. Food Control 83, 69-74.

28. Iversen C, Forsythe S (2004) Isolation of Enterobacter sakazakii and other Enterobacteriaceae from powdered infant formula milk and related products. Food Microbiol 21, 771-7.

29. Delétoile A, Decré D, Courant S, Passet V, Audo J, Grimont P, Arlet G, Brisse S (2009) Phylogeny and identification of Pantoea species and typing of Pantoea agglomerans strains by multilocus gene sequencing. J Clinl Microbiol 47, 300-10.

30. Gomes TAT, Elias WP, Scaletsky ICA, Guth BEC, Rodrigues JF, Piazza RMF, Ferreira LCS, Martinez MB (2016) Diarrheagenic Escherichia coli. Braz J Microbiol 47, 3-30.

31. Beuchat LR, Komitopoulou E, Beckers H, Betts RP, Bourdichon F, Fanning S, Joosten HM, Ter Kuile BH (2013) Low-water activity foods: Increased concern as vehicles of Foodborne pathogens. J Food Prot 76, 150-72.

32. Amagliani G, Brandi G, Schiavano GF (2012) Incidence and role of Salmonella in seafood safety. Food Res Int 45, 780-8.

33. Rattanadilog Na Puket T (2013) Biological activity of ALFSp1 and arasin-likeSp antimicrobial peptides against foodborne pathogenic bacteria. MSc thesis, Chulalongkorn University.

34. Pilet MF, Leroi F (2010) Applications of protective cultures, bacteriocins and bacteriophages in fresh seafood and seafood products. In: Lacroix C (ed) Protective Cultures, Antimicrobial Metabolites and Bacteriophages for Food and Beverage Biopreservation, Woodhead Publishing, Sawston, Cambridge, pp 324-47.

35. Ayed HB, Maalej H, Hmidet N, Nasri M (2015) Isolation and biochemical characterisation of a bacteriocin-like substance produced by Bacillus amyloliquefaciens An6. J Glob Antimicrob Resist 3, 255-61.

36. Hereu A, Bover-Cid S, Garriga M, Aymerich T (2012) High hydrostatic pressure and biopreservation of drycured ham to meet the food safety objectives for Listeria monocytogenes. Int J Food Microbiol 154, 107-12.

37. Liu G, Kong Y, Fan Y, Geng C, Peng D, Sun M (2017) Whole-genome sequencing of Bacillus velezensis LS69, a strain with a broad inhibitory spectrum against pathogenic bacteria. $J$ Biotechnol 249, 20-4.

38. Scholz R, Vater J, Budiharjo A, Wang Z, He Y, Dietel K, Schwecke T, Herfort S, et al (2014) Amylocyclicin, a novel circular bacteriocin produced by Bacillus amyloliquefaciens FZB42. J Bacteriol 196, 1842.

39. Malanovic N, Lohner K (2016) Antimicrobial peptides targeting gram-positive bacteria. Pharmaceuticals 9,59 . 